\title{
Photograph Based Evaluation of Consumer Expectation on Healthiness, Fullness, and Acceptance of Sandwiches as Convenience Food
}

\author{
Purificación García-Segovia ${ }^{1, *(\mathbb{D}}, \mathrm{M}^{\mathrm{a}}$ Jesús Pagán-Moreno $^{1} \mathbb{D}$, Amparo Tárrega $^{2} \mathbb{D}$ and Javier Martínez-Monzó ${ }^{1} \mathbb{( D}$ \\ 1 Food Technology Department, Universitat Politècnica de València, 46022 Valencia, Spain; \\ jpagan@tal.upv.es (M.J.P.-M.); xmartine@tal.upv.es (J.M.-M.) \\ 2 Instituto de Agroquímica y Tecnología de Alimentos (IATA-CSIC), 46980 Paterna, Spain; atarrega@iata.csic.es \\ * Correspondence: pugarse@tal.upv.es; Tel.: +34-96-387-9694
}

Citation: García-Segovia, P.; Pagán-Moreno, M.J.; Tárrega, A.; Martínez-Monzó, J. Photograph Based Evaluation of Consumer Expectation on Healthiness, Fullness, and Acceptance of Sandwiches as Convenience Food. Foods 2021, 10 , 1102. https://doi.org/10.3390/ foods10051102

Academic Editors: Luís Miguel Cunha, Ana Pinto de Moura and Derek V. Byrne

Received: 2 March 2021

Accepted: 13 May 2021

Published: 16 May 2021

Publisher's Note: MDPI stays neutral with regard to jurisdictional claims in published maps and institutional affiliations.

Copyright: (c) 2021 by the authors. Licensee MDPI, Basel, Switzerland. This article is an open access article distributed under the terms and conditions of the Creative Commons Attribution (CC BY) license (https:// creativecommons.org/licenses/by/ $4.0 /)$

\begin{abstract}
Sandwiches are the most common "casual-food" consumed by all age groups in Spain. Due to the importance of visual appearance to promote unplanned or impulse buying, foodservice and hospitality companies focus on improving the visual impression of their food menus to create an expectation that satisfies both sensory and hedonic consumer experiences. To provide a list of attributes about the visual appearance of sandwiches, 25 students were recruited from a university and were invited to participate in two nominal group technique (NGT) sessions. To understand whether a sandwiches' appearance can influence the expectation of consumers, 259 participants completed an online survey specially designed from the results of the NGT sessions. Data were analyzed using conjoint, internal preference mapping and cluster analysis; the interaction effect by gender was also studied. The conjoint results indicate that visual perception about the filling (vegetal or pork based) plays the most key role overall in consumer expectation. When consumers choose vegetables as the filling, the consumers' perceived sandwiches as healthier, but the pork filling was perceived as more attractive and satiating. Interaction effect by gender was observed in filling when females perceived pork filling as less healthy than vegetable. By acceptance, consumers were segmented into three groups. The first cluster $(n=80)$ selected the pork filling. The smaller group (cluster $3, n=36)$ prioritized the vegetal filling, and the most numerous cluster $2(n=140)$ liked sandwiches with multigrain bread. These results may help companies to build tailor-made marketing strategies to satisfy consumer segments.
\end{abstract}

Keywords: visual assessment; sandwiches; consumer expectations; acceptance; healthiness

\section{Introduction}

Food choice is a complex process that influences consumers' nutrient intake in a food company's new product development [1,2]. Beyond satisfying physical hunger, people's food choices are conditioned by previous individual experiences, and culturally shared expectations created on foods. The hedonic response to how a new food is perceived will depend on the divergence between the sensory attributes and the prior expectations, and on other inherent factors from the consumer [3]. These expectations may influence decisions about ingredients, portion size, food type, and nutritional properties. Within the context of sensory analysis and food acceptance research, the cognitive construct of expectations can be applied to both sensory and hedonic experience [4].

The decision to purchase a food item results from two opposite cognitive processes: intuition and rational thinking. Intuitive processes are fast, automatic, and emotional, whereas rational thinking is a slow, effortful, and controlled process [2,5]. Aspects such as food price and health claims can be considered as rational thinking whereas factors such as purchase environment, promotion, packaging, and mood are related to an impulse or intuitive purchase [6,7]. Likewise, Spence et al. [8] suggested that visual appearance 
promotes unplanned or impulse buying food items, whereas sensory properties prioritize food quality. Previous studies [9,10] investigated the impact of color and color combinations on visual attractiveness in food. These investigations showed evidence that he visual attractiveness of food affects its acceptance. Miao and Mattila [11] studied what food motive (health or indulgence) influence consumers' impulse buying behavior. Their results suggested that people prioritized emotional needs ("feel good") versus primary needs ("feel healthy"). Since food choice plays a critical role to have long and healthy lives, it is necessary to understand which factors play a crucial role in decision-making (rational or impulsive) of food [8]. Healthiness and attractiveness are a complex concept that may be gender biased. The effect of gender differences in diet and social media [12] and online cooking [13] has been investigated to provide food recommendations taking into account these differences and to know how gender differences impact in the field of diet, cooking, internet, and food preferences.

An interesting study applying machine learning techniques to predict the preferred recipes using low-level image features and recipe meta-data as predictors was presented by Elsweiler et al. to improve the selection of recipes towards healthier $[14,15]$.

To attract potential customers' attention to particular food items, the food service and hospitality industries have paid greater attention to improve the visual impression of the food selection, to persuade consumers to buy their products [16]. Visual appearance is a key factor for affective responses toward the food we choose and eat [17]. Using visual stimuli in consumer studies has also increased during the last years [18-25]. Using images of food is easier than manipulating food products in research in the eating domain [26]. Moreover, the visual appearance packaging $[4,27,28]$ may also create expectations in the consumer who may be interested in purchasing the product. In this context, it is important to rely on methodologies that allow precise identification of consumer expectations generated by visual impression.

The nominal group technique (NGT) is a qualitative methodology for data collection that can assess consumer preferences and ranking information [29,30]. In the NGT basic method, the numbers each problem/solution/decision receives are counted, and the solution with the highest (i.e., most favored) total ranking is selected as the final decision [31]. This technique could be an interesting tool for exploring consumers' expectations of food products.

Sandwiches are the most "casual-foods" consumed by all age groups in Spain [32]. Typically, the chain restaurants specializing in sandwiches offer their products through attractive images to capture consumer attention to drive their food choice. Thus, they were the foods selected for this study where consumer expectations are evaluated through visual appearance of these products.

An extensive literature exists showing relationship between visual appearance and consumer expectations for a particular food [17,33]. The objectives of this work were (i) to obtain a list of attributes about the visual appearance driving the consumer to select a sandwich and (ii) to understand whether the appearance of sandwiches can influence the consumers' expectation.

\section{Materials and Methods}

\subsection{Nominal Group Technique (NGT) Procedure}

Two NGT sessions, lasting between 1 and $1.5 \mathrm{~h}$ each, were held at the Universitat Politècnica de València in January 2016. A total of 25 participants were recruited between Food Science and Technology undergraduate students regarding a consumption profile (consumption of a sandwich at least once a week). All students participated in both sessions. Nominal groups were conducted according to standard procedures like those recommended by Delbecq and Van de Ven [34]. The Special Committee was informed, and this study reviewed, approved, and all participants singed an informed consent before each session. 
In the first session, a context was evoked reading a brief at the beginning of the session. After, this sentence was written on blackboard to be present all session. The sentence was: "Imagine that it is lunchtime, you are at your favorite casual-food restaurant and you have to choose a sandwich to lunch". They were asked, "What could drive your decision to choose a sandwich? What do you expect from a sandwich?" [35]. Then participants worked individually for $5 \mathrm{~min}$ to generate written responses (words or short phrases) for those questions. After this period, they shared their answers with the group in a round-robin fashion, and finally they ranked the items that were most relevant to them [29].

The structure to the second session was the same and participants were asked to generate responses to the question: "what is, in your opinion, the most important characteristic in a sandwich?". Like the previous session, participants answered the question individually and then shared their responses and classified the attributes of the generated list according to their importance.

In both sessions, all responses were discussed with the research team. Similar items were combined when participants, through consensus [31], provided no distinction. Conclusions from these sessions were used to identify attributes, level, and consumer expectations for experimental design.

\subsection{Experimental Design, Sample Preparation, and Food Image Capture}

Attributes and levels of sandwiches were defined based on data analyzed from the NGT discussion. The platform used for online surveys recommended an average duration from 10 to $15 \mathrm{~min}$ to respond a questionnaire to reduce the quit rate. A pilot test to check how long it was taking to answer questionnaires with three experimental designs was carried out before launch the survey. In these pilot trial, the three, four, and five characteristics in a sandwich obtained in Q3, were used obtaining 8, 16, and 64 sandwiches combinations. Considering time to answer, an experimental design by four attributes with two levels for each one was planned and a series of 16 sandwiches were tested. The experimental design used, and a preliminary version of the picture of the sandwich's samples is presented in Table 1.

Table 1. Description of the sandwiches evaluated by consumers following the experimental design.

\begin{tabular}{ccccc}
\hline Sandwich & Filling & $\begin{array}{c}\text { Kind of } \\
\text { Bread }\end{array}$ & $\begin{array}{c}\text { Shape of } \\
\text { Bread }\end{array}$ & $\begin{array}{c}\text { Making } \\
\text { Sandwich }\end{array}$ \\
\hline 1 & Pork & Multigrain & Loaf & Fresh \\
2 & Vegetal & Multigrain & Loaf & Fresh \\
3 & Pork & Multigrain & Loaf & Toasted \\
4 & Vegetal & Multigrain & Loaf & Toasted \\
5 & Pork & Multigrain & Round & Fresh \\
\hline 6 & Vegetal & Multigrain & Round & Fresh \\
\hline
\end{tabular}


Table 1. Cont.

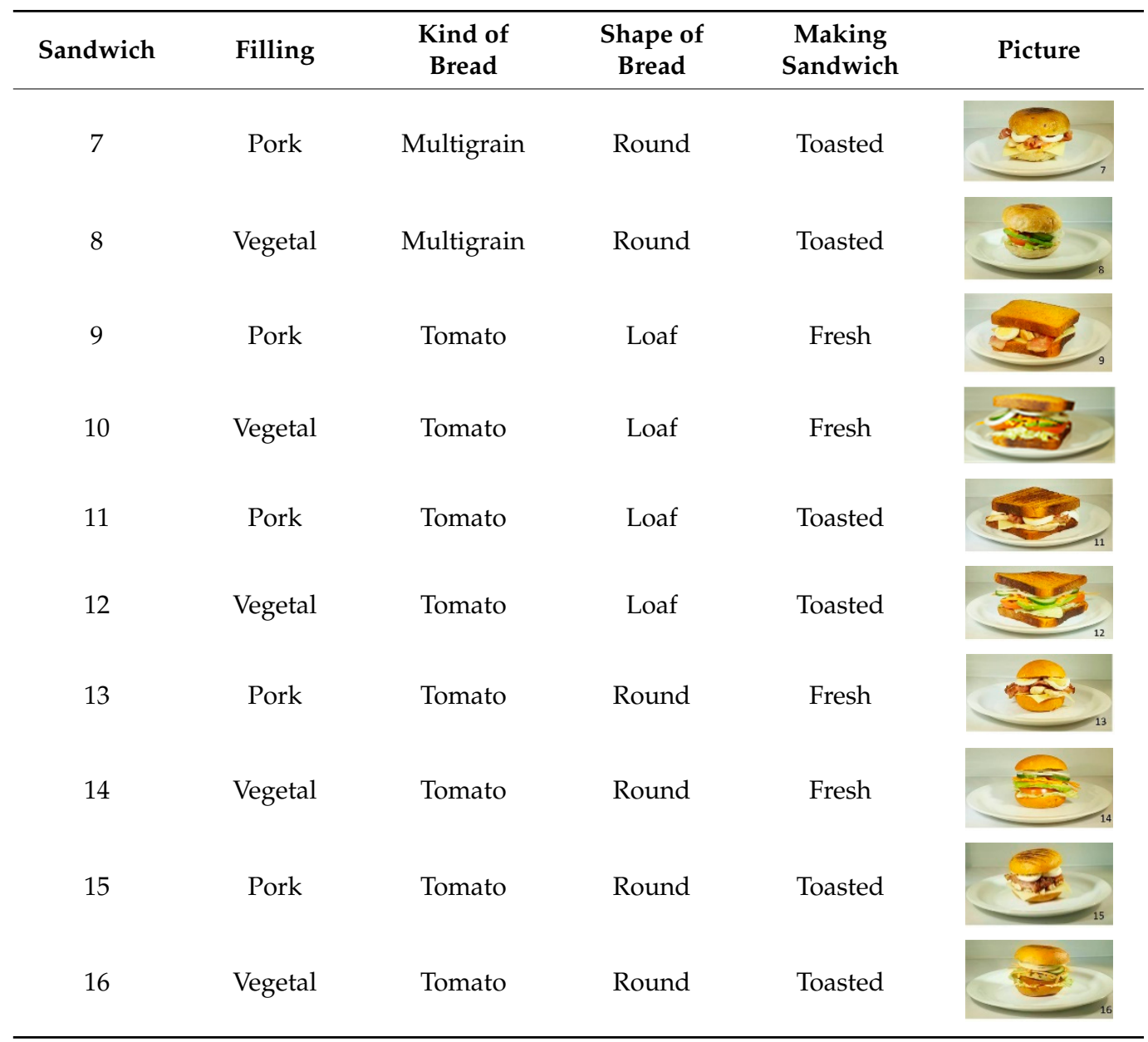

Sandwiches were prepared in the Nutrition Laboratory at University just before taking the pictures. The caloric value was calculated according to the Spanish Food Composition Database [36].

For each sandwich, a set of photographs was taken using a high-resolution digital camera model Sony $\alpha-3000$ (Sony Corp., Minato, Tokyo, Japan). Each sandwich was photographed on the same white plate ( $255 \mathrm{~mm}$ diameter). Care was taken to maintain a constant lighting condition and viewing angle in each photograph.

\subsection{Online Survey: Participants and Experimental Procedure}

Two hundred and fifty-nine participants (148 female and 111 male) participated in the study. The participants were randomly recruited using purposive convenience sampling. This non-probability method is perhaps used more often than any other sampling in behavioral science research during preliminary research, or when the goal is to reach a gross estimate of results related to a research subject [37-39]. Recruitment was via email in Valencia (Spain), based on specific criteria: interest in participating in the study, consumption of sandwich at least once a week, to be omnivorous, without food allergies or intolerances. At the recruitment stage, no information about the specific aim of the study was provided.

The electronic questionnaire implemented for this task was designed in RedJade ${ }^{\circledR}$ Online Survey Tool (Redjade Sensory Solutions, LLC, Martinez, CA, USA) including questions about consumer profiles (gender, age, and food frequency sandwiches intake). To introduce test consumers who were asked to imagine that they were going to the snack bar to buy a sandwich. After this introduction, respondents were asked to value each of the 16 sandwiches pictures, which were presented in a randomized order. To measure 
consumer's expectations, a 9-point hedonic scale was used. The link to the form was sent to all participants via e-mail. The online questionnaire was available for 1 week.

\subsection{Data Analysis}

To identify which attributes and levels have the most influence in choice, purchase, and acceptance on consumers' expectations, conjoint analysis is one of the most widely used methodologies [40,41]. The technique can identify the combination of attributes that utilize the consumer and the relative importance (RI) of predefined attributes in total utility. Conjoint and Cluster Analyses, using XLSTAT Sensory 2021.1.1 (Addinsoft, New York, NY, USA), analyzed responses from online questionnaires [42].

Conjoint measurement was run to evaluate the joint effect of the independent variables (attributes and level of sandwiches) on the ordering of the dependent variables (consumers' expectations). Similarly, Two-way ANOVA was made to assess gender interaction with sandwiches' attributes.

An internal preference mapping was performed for consumer acceptance evaluated to segment the consumers into groups of similar criteria, data from the other variables measured were introduced in PCA as supplementary variables. In a second stage, a ' $k$ means' clustering followed by an agglomerative hierarchical clustering (AHC) was used to identify distinct patterns in the responses. If required, conjoint analysis was conducted to each cluster to test if there is a significant difference in each consumers' expectations between attribute-level combinations.

\section{Results and Discussion}

\subsection{Nominal Group Technique (NGT)}

The aim in the first session with NGT was to select dependent variables (expectations when consumers getting a sandwich) to prepare a questionnaire online in the next survey step. Responses to question 1 (What drove your decision to choose a sandwich?) and 2 (What do you expect from a sandwich?) from the NGT are listed and ranked as seen in Table 2.

Table 2. Nominal group technique: Top 10 responses to the questions Q1 and Q2

\begin{tabular}{cccc}
\hline Q1. What Drove Your Decision to Choose a Sandwich? & \multicolumn{2}{c}{ Q2. What Do You Expect from a Sandwich? } \\
\hline Responses & Total Votes & Responses & Total Votes \\
\hline Attractiveness & 23 & It seems/taste good & 25 \\
Healthy aspect & 21 & Fullness/be satisfied & 22 \\
Desire to eat & 21 & Healthy & 20 \\
Fullness/be satisfied & 20 & Desire to eat & 18 \\
Caloric value & 17 & Freshly made & 15 \\
Price & 15 & Adjusted price/quality & 14 \\
Succulent & 10 & Easy to eat & 10 \\
Easy to eat & 9 & Can eat with fingers & 8 \\
Can eat with fingers & 6 & Crisp, well-baked, well-filling & 7 \\
To be hungry & 5 & Convenience packaged & 5 \\
\hline
\end{tabular}

Comparing results of NGT for Q1 and Q2, "expectations when people get a sandwich" vs. "driven decision to choose a sandwich", respondents from both questions mentioned same items: "Attractive/seems good" (translated from "apetecible" in Spanish), "to be healthy", "fullness/feel full", and "acceptance/willing to eat" (defined in Spanish as "que me guste"). The most important parameters for all participants, when they select a sandwich, were related to the aspect (healthy, attractiveness, and desirable), and fullness. According to the NGT methodology, participants and the research team discussed the answers and through consensus and selected the top four items as dependent variables to include as questions in the online survey. Using information gathered in the second NGT session, attributes and levels of sandwiches were defined based on responses for 
question 3, "What's the most important characteristic in a sandwich?" (Table 3). The investigative team discussed and arrived at a consensus with NGT participants to select the key attributes/levels and define the experimental design.

Table 3. Responses to the question Q3.

\begin{tabular}{ccc}
\hline \multicolumn{2}{c}{ Q3. What's the Most Important Sandwich Characteristic? } & \\
\cline { 1 - 2 } Attributes & Total Votes \\
\hline Filling & Level & \\
& Pork & 25 \\
Sandwich preparation & Veggie & 15 \\
& Fresh & 10 \\
Bread shape (easy to eat) & Toast & 9 \\
& & 9 \\
Kind of bread & Round & 17 \\
& Loaf & 10 \\
Price (€) & High fiber & 7 \\
& Flavored & 11 \\
& $<2$ & 6 \\
& $2-2.5$ & 5 \\
Size & $2.5-3$ & 8 \\
& $>3$ & 1 \\
& Normal & 3 \\
Not staining filling & Big & 3 \\
Flavor & & 1 \\
& Spice & 5 \\
& Dairy (cheese) & 2 \\
& & 4 \\
& & 3 \\
& & 1 \\
\hline
\end{tabular}

Table 1 shows the experimental design used where attributes and levels were defined as: (1) sandwich filling: vegetable or pork based; (2) kind of bread: multigrain or tomato; (3) shape of bread: loaf or round; (4) sandwich preparation: toasted or fresh.

Although the sandwiches contained different ingredients, they were prepared to get the same final weight. Table 4 shows the ingredients and weight of each one of the different sandwiches. The average weight of each was $215 \pm 5 \mathrm{~g}$ for vegetable and $220 \pm 4 \mathrm{~g}$ in pork sandwiches.

Table 4. List of ingredients and weight of designed sandwiches.

\begin{tabular}{lcc}
\hline Sandwich & Ingredients & Grams \\
\hline \multirow{3}{*}{ Pork } & Bread & 50 \\
\cline { 2 - 3 } & Pork loin & 75 \\
\cline { 2 - 3 } & Bacon & 25 \\
\cline { 2 - 3 } & Egg & 25 \\
\cline { 2 - 3 } & Cheese & 20 \\
\cline { 2 - 3 } & Fried onion & 25 \\
& Total & 220 \\
\hline
\end{tabular}


Table 4. Cont.

\begin{tabular}{lcc}
\hline Sandwich & Ingredients & Grams \\
\hline \multirow{3}{*}{ Vegetal } & Bread & 50 \\
\cline { 2 - 3 } & Lettuce & 10 \\
\cline { 2 - 3 } & Tomato & 40 \\
\cline { 2 - 3 } & Avocado & 50 \\
\cline { 2 - 3 } & Cucumber & 25 \\
\cline { 2 - 3 } & Carrot & 25 \\
\cline { 2 - 3 } & Fresh onion & 215 \\
\hline
\end{tabular}

\subsection{Online Survey}

A total of 256 men and women participated in the online survey, filling all questions. Their ages varied from 20 to 65 , where $46.1 \%$ had $\leq 25,35.6 \%$ were $26-45$, and $27.4 \%$ were 46-65. Responses to questions about consumer's profile (gender, age, food frequency sandwiches intake, and willing to pay) are shown in Table 5.

Table 5. Consumer's profile $(n=256)$.

\begin{tabular}{|c|c|c|c|}
\hline & All & Female & Male \\
\hline & $(n=256) \%$ & $(n=145) \%$ & $(n=111) \%$ \\
\hline & & 56.6 & 43.4 \\
\hline \multicolumn{4}{|l|}{ Age (years) } \\
\hline$<25$ & 46.1 & 49.7 & 41.4 \\
\hline $26-35$ & 16.8 & 16.6 & 17.1 \\
\hline $36-45$ & 18.8 & 17.2 & 20.7 \\
\hline $46-55$ & 12.9 & 11.0 & 15.3 \\
\hline $55-65$ & 5.5 & 5.5 & 5.4 \\
\hline$>65$ & 0.0 & 0.0 & 0.0 \\
\hline \multicolumn{4}{|c|}{ Frequency of consumption (\%) } \\
\hline Never & 0.0 & 0.0 & 0.0 \\
\hline Occasionally & 9.0 & 9.0 & 9.0 \\
\hline$<4$ & 25.8 & 29.0 & 21.6 \\
\hline Between 4-8 & 31.6 & 31.0 & 32.4 \\
\hline$>8$ & 33.6 & 31.0 & 36.9 \\
\hline \multicolumn{4}{|c|}{ Willing to pay $(€)$} \\
\hline$<2$ & 10.9 & 9.7 & 12.6 \\
\hline $2-2.5$ & 38.7 & 40.7 & 36.0 \\
\hline $2.5-3$ & 40.2 & 37.9 & 43.2 \\
\hline$>3$ & 10.2 & 11.7 & 8.1 \\
\hline
\end{tabular}

Of the data collected from the 265 respondents' online questionnaire, nine data responses were unusable for analysis because the participants failed to complete all questions.

Data were analyzed, individually generating a utility value of each level and the utility importance value of each attribute in each consumer's expectation (Table 6). 
Table 6. Conjoint analysis results for each consumers' expectations between attributes-level combinations.

\begin{tabular}{|c|c|c|c|c|c|c|c|c|}
\hline \multirow[b]{2}{*}{$\begin{array}{l}\text { Consumer's } \\
\text { Expectations }\end{array}$} & \multirow[b]{2}{*}{ Attributes } & \multirow[b]{2}{*}{ Levels } & \multicolumn{2}{|c|}{$\begin{array}{l}\text { All Consumers } \\
\quad(n=256)\end{array}$} & \multicolumn{2}{|c|}{$\begin{array}{l}\text { Female Group } \\
\quad(n=146)\end{array}$} & \multicolumn{2}{|c|}{$\begin{array}{l}\text { Male Group } \\
(n=110)\end{array}$} \\
\hline & & & $\begin{array}{c}\text { Utility } \\
\text { Estimate }\end{array}$ & $\begin{array}{l}\text { Importance } \\
\text { Values }\end{array}$ & $\begin{array}{c}\text { Utility } \\
\text { Estimate }\end{array}$ & $\begin{array}{l}\text { Importance } \\
\text { Values }\end{array}$ & $\begin{array}{l}\text { Utility } \\
\text { Estimate }\end{array}$ & $\begin{array}{l}\text { Importance } \\
\text { Values }\end{array}$ \\
\hline \multirow{4}{*}{ Fullness } & Filling & $\begin{array}{c}\text { Pork } \\
\text { Vegetal }\end{array}$ & $\begin{array}{c}0.963 \\
-0.963\end{array}$ & 77.3 & $\begin{array}{c}-0.024 \\
0.024\end{array}$ & 23.4 & $\begin{array}{c}0.032 \\
-0.032\end{array}$ & 23.4 \\
\hline & $\begin{array}{c}\text { Kind of } \\
\text { bread }\end{array}$ & $\begin{array}{l}\text { Multigrain } \\
\text { Tomato }\end{array}$ & $\begin{array}{c}-0.048 \\
0.048\end{array}$ & 3.9 & $\begin{array}{l}-0.036 \\
0.036\end{array}$ & 35.2 & $\begin{array}{c}0.048 \\
-0.048\end{array}$ & 35.2 \\
\hline & $\begin{array}{l}\text { Shape of } \\
\text { bread }\end{array}$ & $\begin{array}{l}\text { Loaf } \\
\text { Round }\end{array}$ & $\begin{array}{c}-0.17 \\
0.17\end{array}$ & 13.6 & $\begin{array}{c}-0.035 \\
0.035\end{array}$ & 33.6 & $\begin{array}{c}0.046 \\
-0.046\end{array}$ & 33.6 \\
\hline & $\begin{array}{l}\text { Sandwich } \\
\text { preparation }\end{array}$ & $\begin{array}{l}\text { Fresh } \\
\text { Toasted }\end{array}$ & $\begin{array}{l}-0.065 \\
0.065\end{array}$ & 5.2 & $\begin{array}{c}0.008 \\
-0.008\end{array}$ & 7.8 & $\begin{array}{c}-0.011 \\
0.011\end{array}$ & 7.8 \\
\hline \multirow{4}{*}{ Healthy } & Filling & $\begin{array}{c}\text { Pork } \\
\text { Vegetal }\end{array}$ & $\begin{array}{l}-1.777 \\
1.777\end{array}$ & 68.2 & $\begin{array}{c}-0.113 \\
0.113\end{array}$ & 81.8 & $\begin{array}{c}0.150 \\
-0.150\end{array}$ & 81.8 \\
\hline & $\begin{array}{c}\text { Kind of } \\
\text { bread }\end{array}$ & $\begin{array}{l}\text { Multigrain } \\
\text { Tomato }\end{array}$ & $\begin{array}{c}0.336 \\
-0.336\end{array}$ & 12.9 & $\begin{array}{c}0.001 \\
-0.001\end{array}$ & 0.6 & $\begin{array}{c}-0.001 \\
0.001\end{array}$ & 0.6 \\
\hline & $\begin{array}{c}\text { Shape of } \\
\text { bread }\end{array}$ & $\begin{array}{l}\text { Loaf } \\
\text { Round }\end{array}$ & $\begin{array}{c}0.213 \\
-0.213\end{array}$ & 8.2 & $\begin{array}{c}-0.014 \\
0.014\end{array}$ & 10.1 & $\begin{array}{c}0.019 \\
-0.019\end{array}$ & 10.1 \\
\hline & $\begin{array}{l}\text { Sandwich } \\
\text { preparation }\end{array}$ & $\begin{array}{l}\text { Fresh } \\
\text { Toasted }\end{array}$ & $\begin{array}{c}0.278 \\
-0.278\end{array}$ & 10.7 & $\begin{array}{c}-0.010 \\
0.010\end{array}$ & 7.6 & $\begin{array}{c}0.014 \\
-0.014\end{array}$ & 7.6 \\
\hline \multirow{4}{*}{ Attractiveness } & Filling & $\begin{array}{c}\text { Pork } \\
\text { Vegetal }\end{array}$ & $\begin{array}{c}0.463 \\
-0.463\end{array}$ & 57.0 & $\begin{array}{c}-0.115 \\
0.115\end{array}$ & 76.4 & $\begin{array}{c}0.153 \\
-0.153\end{array}$ & 76.4 \\
\hline & $\begin{array}{l}\text { Kind of } \\
\text { bread }\end{array}$ & $\begin{array}{l}\text { Multigrain } \\
\text { Tomato }\end{array}$ & $\begin{array}{l}-0.037 \\
0.037\end{array}$ & 4.6 & $\begin{array}{c}-0.019 \\
0.019\end{array}$ & 12.4 & $\begin{array}{c}0.025 \\
-0.025\end{array}$ & 12.4 \\
\hline & $\begin{array}{l}\text { Shape of } \\
\text { bread }\end{array}$ & $\begin{array}{l}\text { Loaf } \\
\text { Round }\end{array}$ & $\begin{array}{l}-0.122 \\
0.122\end{array}$ & 15.0 & $\begin{array}{c}0.013 \\
-0.013\end{array}$ & 8.4 & $\begin{array}{c}-0.017 \\
0.017\end{array}$ & 8.4 \\
\hline & $\begin{array}{l}\text { Sandwich } \\
\text { preparation }\end{array}$ & $\begin{array}{l}\text { Fresh } \\
\text { Toasted }\end{array}$ & $\begin{array}{c}-0.191 \\
0.191\end{array}$ & 23.5 & $\begin{array}{c}0.004 \\
-0.004\end{array}$ & 2.7 & $\begin{array}{c}-0.005 \\
0.005\end{array}$ & 2.7 \\
\hline \multirow{4}{*}{ Acceptance } & Filling & $\begin{array}{c}\text { Pork } \\
\text { Vegetal }\end{array}$ & $\begin{array}{c}0.393 \\
-0.393\end{array}$ & 70.4 & $\begin{array}{c}-0.102 \\
0.102\end{array}$ & 60.4 & $\begin{array}{c}0.135 \\
-0.135\end{array}$ & 60.4 \\
\hline & $\begin{array}{c}\text { Kind of } \\
\text { bread }\end{array}$ & $\begin{array}{l}\text { Multigrain } \\
\text { Tomato }\end{array}$ & $\begin{array}{c}0.116 \\
-0.116\end{array}$ & 20.8 & $\begin{array}{c}-0.043 \\
0.043\end{array}$ & 25.7 & $\begin{array}{c}-0.057 \\
0.057\end{array}$ & 25.7 \\
\hline & $\begin{array}{c}\text { Shape of } \\
\text { bread }\end{array}$ & $\begin{array}{l}\text { Loaf } \\
\text { Round }\end{array}$ & $\begin{array}{c}0.029 \\
-0.029\end{array}$ & 5.2 & $\begin{array}{c}0.014 \\
-0.014\end{array}$ & 8.5 & $\begin{array}{c}-0.019 \\
0.019\end{array}$ & 8.5 \\
\hline & $\begin{array}{l}\text { Sandwich } \\
\text { preparation }\end{array}$ & $\begin{array}{l}\text { Fresh } \\
\text { Toasted }\end{array}$ & $\begin{array}{c}-0.02 \\
0.02\end{array}$ & 3.6 & $\begin{array}{c}0.009 \\
-0.009\end{array}$ & 5.4 & $\begin{array}{c}-0.012 \\
0.012\end{array}$ & 5.4 \\
\hline
\end{tabular}

Note: Grey color marks the Importance Value most relevant in each consumer expectations.

Utility estimate referred numerical scores that measure how much each feature influences the customer's decision to make that choice. Importance values aggregate into one set consumer preferences of attribute-level utilities. Analyzing the results showed in Table 6 importance values vary for each consumer's expectation. To "fullness", the sequence of the highest positive utility values was in decreasing order: filling, bread shape, sandwich preparation, and type of bread. For healthy perception, the highest positive sequence was filling, kind of bread, sandwich preparation, and the shape of bread. For the attractiveness, filling, sandwich preparation, shape, and kind of bread was the positive sequence defined by respondents. Filling and kind of bread were the most valued acceptance attributes.

For all consumers' conjoint expectation analysis, results indicate that filling (pork or vegetable) was the most valued attribute that affects consumer preferences of sandwiches. Filling, as the key attribute, has the highest utility value for "pork filling" in the consumer's expectations "fullness", "attractiveness", and "acceptance" but it was a negative utility when the "healthy" perception was evaluated.

Consumers chose vegetables for the filling, which indicates that they perceived these as healthier, but pork filling was identified as more attractive and satiating. An explanation for this perception of healthiness of vegetables could be that this product has a strong health image versus pork, conveyed to the consumers like the concept low in calories. A study from Rebollar et al. [43] shows a clear relationship between the attributes of low-calories and healthy. The Mediterranean diet (MD) was defined as a daily intake of plant foods and moderate amounts of meat; its recommendations have had a substantial impact as the best "healthy eating model". Thus, consumer perception of sandwiches can be related to 
consumer's experience and learning about MD, suggesting this can improve acceptance ratings in choice behavior [44-46].

\subsection{Internal Preference Mapping and Cluster Analysis}

An internal preference map was obtained from principal components analysis (PCA) of the four consumer's expectation data (Figure 1). The two principal components explained $67.21 \%$ of the variance for "acceptance". The dispersion of consumers on the right of the graph indicated some common acceptance pattern between consumers on the F1 but some differences at the same time on the F2. In the Figure 1, F1 separates the "vegetable filling" (S2, S4, S6, S8, S10, S12, S14, and S16) from the "pork filling" (S1, S3, S5, S7, S9, S11, S13, and S15) sandwiches, whereas F2 separates multigrain versus tomato bread. S1 presented a high positive contribution on F2, different than others probably because it is recognized as the most of the most classic and demanded sandwich at Spanish lunch. S1 opposed to the location of $\mathrm{S} 13$, showed that even if these two sandwiches had a high consumer's acceptability, they were not chosen by the same consumers, those who preferred S1(porkmultigrain-loaf-fresh) did not choose S13 (pork-tomato-round-fresh).

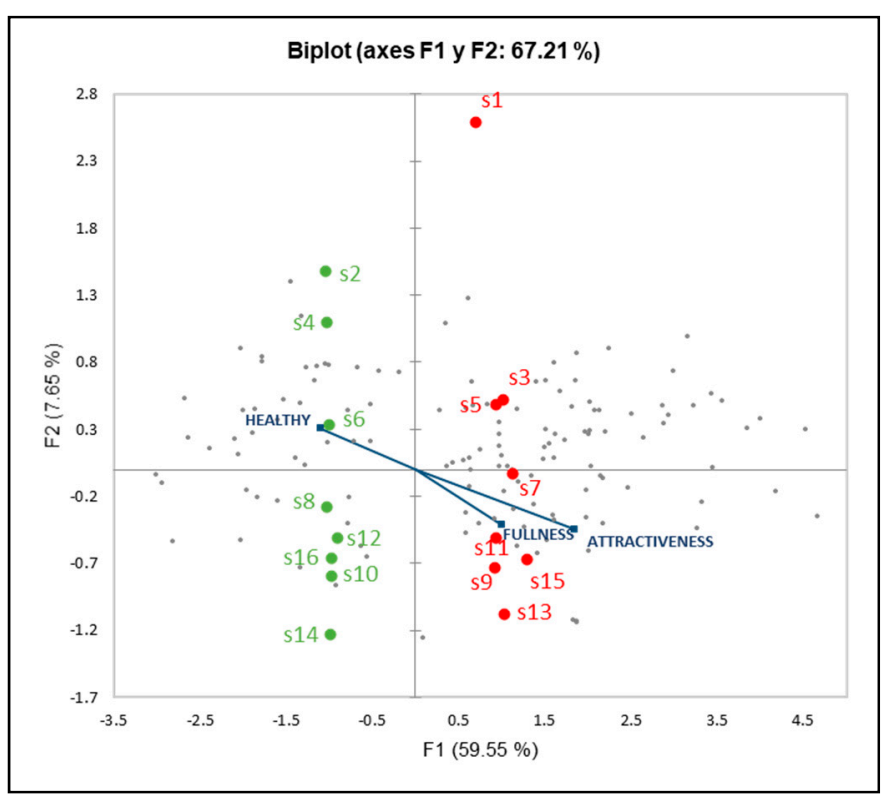

Figure 1. Consumer internal preference map obtained from acceptance ratings and projection of fullness, healthy, and attractiveness as supplementary variables.

Projection of the other consumer's expectation on IPM allowed to observe the relation with acceptability. Sandwiches with pork filling generated a greater expectation of "fullness". Vegetal filling sandwiches were observed as a negative value on the first component, with S2 and S4 were the least "fullness" values. According to Fiszman et al. [47], the pork meat could be associated with a harder texture and anticipated to the consumers a prolonged oral processing and oral exposure, contributing to "fullness" perception in pork sandwiches.

To study segmentation observed in PCA, k-means clustering followed by AHC was used to identify distinct patterns.

Two clusters with different attractiveness patterns were obtained (Figure 2a). Cluster $1(n=86)$ prioritizes "pork filling" as the key attribute in attractiveness. Cluster $2(n=170)$ showed a marked preference for "vegetal filling", and values positively "toasted bread." Both consider the kind of bread (multigrain or tomato flavor) as a less important motivating preference by attractiveness. 


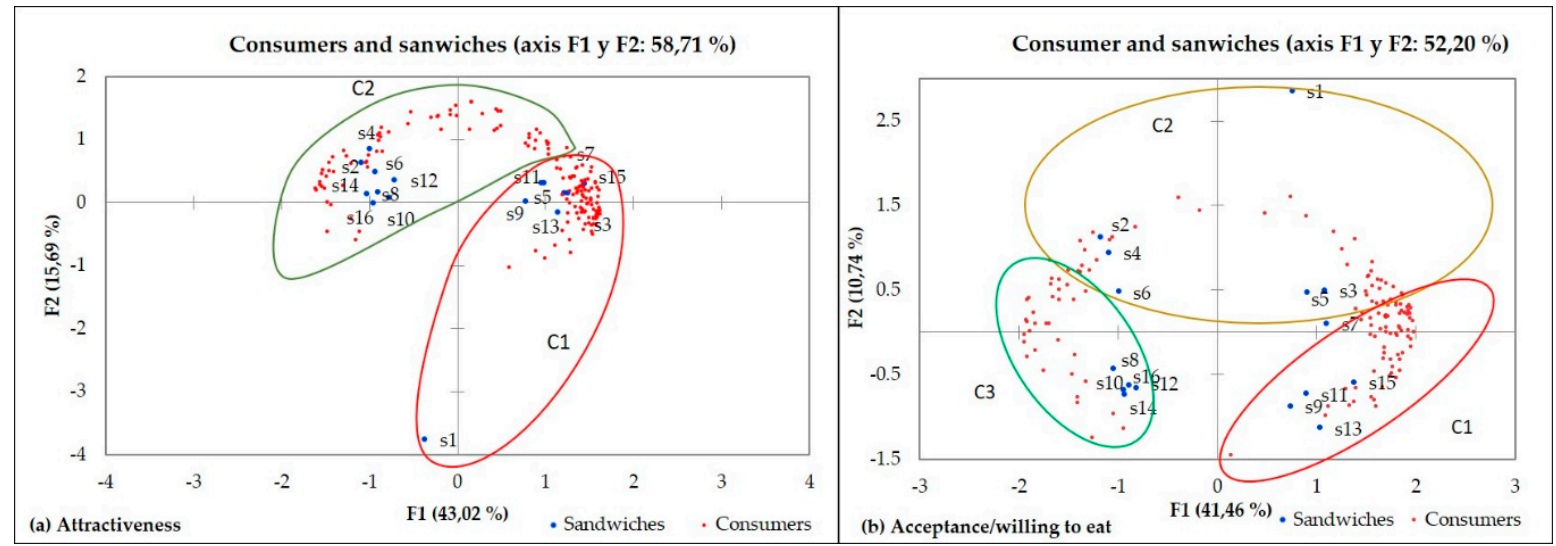

Figure 2. Clusters of respondents for (a) attractiveness; (b) acceptance.

For acceptance, consumers were segmented into three groups (Figure $2 b$ ): the first cluster $(n=80)$ selects pork filling. The smaller group (cluster $3, n=36$ ) prioritize vegetal filling, and the most numerous cluster $2(n=140)$ liked sandwiches with multigrain bread. Previous studies of consumer's perceptions of bread [48-51] or market trends [52] found higher health-related perceptions of whole grain and high-fiber grain bread. This could explain the high consumer segment with preference for multigrain bread sandwiches in our study.

The results of the ANOVA test for each consumer's expectation (or their clusters) are presented in Table 7, confirming a significant difference in the attributes for "fullness" and "healthy" and between clusters for "attractiveness" and "acceptance". In all cases, "filling" was the major contributing attribute.

Table 7. ANOVA to test significant differences between attributes-level combinations in the consumer' expectations.

\begin{tabular}{ccccccc}
\hline \multirow{2}{*}{ Consumer's Expectations } & \multicolumn{2}{c}{ Model } & \multicolumn{2}{c}{ Error } \\
\cline { 2 - 7 } & Mean Squares & df & Mean Squares & df & F & Pr $>$ F \\
\hline Fullness $(n=256)$ & 986.7163 & 4 & 3.9198 & 4091 & 251.7290 & $<0.0001$ \\
Healthy $(n=256)$ & 3474.4797 & 4 & 3.7065 & 4091 & 937.3898 & $<0.0001$ \\
Attractiveness $(n=256)$ & 273.6882 & 4 & 5.7710 & 4091 & 47.4248 & $<0.0001$ \\
Cluster 1 $(n=86)$ & 1404.9397 & 4 & 4.0054 & 1371 & 350.7595 & $<0.0001$ \\
Cluster 2 $(n=170)$ & 75.3610 & 4 & 4.2681 & 2715 & 17.6569 & $<0.0001$ \\
Acceptance $(n=256)$ & 173.0398 & 4 & 4.9937 & 4091 & 34.6518 & $<0.0001$ \\
Cluster 1 $(n=80)$ & 1013.0570 & 4 & 4.1198 & 1275 & 245.8992 & $<0.0001$ \\
Cluster 2 $(n=140)$ & 15.7353 & 4 & 2.6716 & 2235 & 5.8899 & $<0.0000$ \\
Cluster 3 $(n=36)$ & 414.0191 & 4 & 2.8646 & 571 & 144.5306 & $<0.0001$ \\
\hline
\end{tabular}

\subsection{Gender Effects}

Two-way ANOVA revealed a statistically significant effect for gender in "fullness" and "acceptance" expectations for sandwiches (Table 8). Females expect sandwiches to make them more than males $(\mathrm{F}=7.33(0.04)$ and $\mathrm{M}=6.52(0.05)$, respectively). The same effect was observed in acceptance perception, where women rated significantly higher on the hedonic scale. Male and female subjects did not significantly differ in their expectations in the "healthy" or "attractiveness" of sandwiches $(p>0.05)$. 
Table 8. F-test in two-way ANOVA for gender.

\begin{tabular}{|c|c|c|c|c|c|}
\hline & & Fullness & Healthy & Attractiveness & Acceptance \\
\hline & $R^{2}$ & 0.232 & 0.481 & 0.048 & 0.039 \\
\hline & F & 137.031 & 420.230 & 22.800 & 18.603 \\
\hline & $\operatorname{Pr}>F$ & $<0.0001$ & $<0.0001$ & $<0.0001$ & $<0.0001$ \\
\hline \multirow{2}{*}{ Gender } & $\mathrm{F}$ & 178.036 & 0.004 & 2.028 & 14.354 \\
\hline & $\operatorname{Pr}>F$ & $<0.0001$ & 0.950 & 0.154 & 0.000 \\
\hline \multirow{2}{*}{ Gender $\times$ Filling } & $\mathrm{F}$ & 0.845 & 18.898 & 12.512 & 11.329 \\
\hline & $\operatorname{Pr}>F$ & 0.358 & $<0.0001$ & 0.000 & 0.001 \\
\hline \multirow{2}{*}{ Gender $\times$ Kind of bread } & $\mathrm{F}$ & 1.920 & 0.001 & 0.331 & 2.042 \\
\hline & $\operatorname{Pr}>F$ & 0.166 & 0.976 & 0.565 & 0.153 \\
\hline \multirow{2}{*}{ Gender $\times$ Shape of bread } & $\mathrm{F}$ & 1.743 & 0.289 & 0.151 & 0.222 \\
\hline & $\operatorname{Pr}>F$ & 0.187 & 0.591 & 0.697 & 0.637 \\
\hline \multirow{2}{*}{ Gender $\times$ Sandwich preparation } & $\mathrm{F}$ & 0.094 & 0.161 & 0.016 & 0.091 \\
\hline & $\operatorname{Pr}>F$ & 0.759 & 0.688 & 0.900 & 0.763 \\
\hline
\end{tabular}

Note: Grey color marks significant interaction effects.

There were no significant interaction effects by gender for kind of bread, shape of bread, or sandwich preparation. Interaction effect by gender was only observed in filling for healthy, attractiveness, and acceptance/willing to eat.

Since 1990 some authors have studied the role of gender on food choice [53-56]. Their results suggest that some gender differences might exist concerning total caloric consumption and preferences for certain types of food. However, various authors defined how visual attributes of the product such as color, shape, pattern, and texture could be often associated with gender-based stereotypes about food [57-60]. Similar to the results seen by the previous authors, the results of the present study (see Table 6) showed that the pork filling was perceived as less healthy than vegetable; this difference was most evident for women. Although, men did not perceive vegetable sandwiches as healthier, or pork based as unhealthier. In contrast, men referred to more differences between vegetable and pork filling in attractive perception.

Related to acceptance or willing to eat differed between women's and men's expectations $(p<0.0001)$, women preferred vegetal filling (Table 6).

\section{Conclusions}

The investigation focused on evaluating sandwiches based on visual perception because in the moment of choice, the consumer does not have access to the product. Notwithstanding the limitations, this study could be considered an exploratory study to understand how individuals choose sandwiches in "casual-food" bar by showing the importance of the visual appearance in these choices. These results may help foodservice companies to build tailor-made menu strategies to satisfy different consumer segments. These results contribute to show the relevance of food images in creating consumers' expectations on satisfaction, attractiveness, or healthiness, which could affect their product acceptance.

\section{Limitations}

Like other studies, this research did not include a tasting phase. This phase could be interesting to confirm the expectations generated by the photograph evaluation of the sandwiches, with the "fullness" attribute. On the other hand, the concepts "healthiness", "attractiveness", or "fullness" are complex, difficult to measure, and may be a gender bias. Future studies should be addressed to measure the different concept of healthiness, fulness, and attractiveness in the participants to identify how visual cues affects food choice. The visual evaluation of the pictures could be affected because not all ingredients were seen. Authors are designing a new experience whereby participants will be provided the information about sandwiches ingredients. 
Author Contributions: Conceptualization, P.G.-S., M.J.P.-M. and J.M.-M.; Data curation, P.G.-S. and A.T.; Formal analysis, P.G.-S. and A.T.; Investigation, P.G.-S. and J.M.-M.; Methodology, P.G.S., M.J.P.-M. and J.M.-M.; Resources, P.G.-S.; Supervision, J.M.-M.; Writing-original draft, P.G.-S. Writing-review and editing, M.J.P.-M. and A.T. All authors have read and agreed to the published version of the manuscript.

Funding: This research not received funding.

Informed Consent Statement: Informed consent was obtained from all subjects involved in the study.

Conflicts of Interest: The authors declare no conflict of interest.

\section{References}

1. Köster, E.P. The psychology of food choice: Some often encountered fallacies. Food Qual. Prefer. 2003, 14, 359-373. [CrossRef]

2. Köster, E.P. Diversity in the determinants of food choice: A psychological perspective. Food Qual. Prefer. 2009. [CrossRef]

3. Piqueras-Fiszman, B.; Spence, C. Sensory expectations based on product-extrinsic food cues: An interdisciplinary review of the empirical evidence and theoretical accounts. Food Qual. Prefer. 2015, 40, 165-179. [CrossRef]

4. Deliza, R.; Macfie, H.; Hedderley, D. Use of computer-generated images and conjoint analysis to investigate sensory expectations. J. Sens. Stud. 2003. [CrossRef]

5. Kahneman, D. A perspective on judgment and choice: Mapping bounded rationality. Am. Psychol. 2003, 58, 697-720. [CrossRef] [PubMed]

6. Nurafifah Jaafar, S.; Ein Lalp, P.; Mohamed, M. Consumers' Perceptions, Attitudes and Purchase Intention towards Private Label Food Products in Malaysia. Asian J. Bus. Manag. Sci. 2012, 2, 73-90.

7. Pride, W.M.; Ferrell, O.C. Marketing 2012, 16th ed.; South-Western College Cengage Learning: Boston, MA, USA, 2012; ISBN 1-111-52619-2.

8. Spence, C.; Okajima, K.; Cheok, A.D.; Petit, O.; Michel, C. Eating with our eyes: From visual hunger to digital satiation. Brain Cogn. 2016. [CrossRef] [PubMed]

9. Paakki, M.; Sandell, M.; Hopia, A. Visual attractiveness depends on colorfulness and color contrasts in mixed salads. Food Qual. Prefer. 2019, 76, 81-90. [CrossRef]

10. Zellner, D.A.; Loss, C.R.; Zearfoss, J.; Remolina, S. It tastes as good as it looks! The effect of food presentation on liking for the flavor of food. Appetite 2014, 77, 31-35. [CrossRef] [PubMed]

11. Miao, L.; Mattila, A.S. Impulse Buying in Restaurant Food Consumption. J. Foodserv. Bus. Res. 2013. [CrossRef]

12. Nelson, A.M.; Fleming, R. Gender differences in diet and social media: An explorative study. Appetite 2019, 142, 104383. [CrossRef] [PubMed]

13. Rokicki, M.; Herder, E.; Kuśmierczyk, T.; Trattner, C. Plate and prejudice: Gender differences in online cooking. In Proceedings of the UMAP 2016-Proceedings of the 2016 Conference on User Modeling Adaptation and Personalization, Halifax, NS, Canada, 13-16 July 2016; pp. 207-215. [CrossRef]

14. Elsweiler, D.; Trattner, C.; Harvey, M. Exploiting food choice biases for healthier recipe recommendation. In Proceedings of the SIGIR 2017-Proceedings of the 40th International ACM SIGIR Conference on Research and Development in Information Retrieval, Tokyo, Japan, 7-11 August 2017; pp. 575-584. [CrossRef]

15. Zhang, Q.; Elsweiler, D.; Trattner, C. Visual cultural biases in food classification. Foods 2020, 9, 823. [CrossRef] [PubMed]

16. Zhang, B.; Seo, H.S. Visual attention toward food-item images can vary as a function of background saliency and culture: An eye-tracking study. Food Qual. Prefer. 2015. [CrossRef]

17. Zellner, D.A.; Lankford, M.; Ambrose, L.; Locher, P. Art on the plate: Effect of balance and color on attractiveness of, willingness to try and liking for food. Food Qual. Prefer. 2010, 21, 575-578. [CrossRef]

18. Olsson, V.; Skog, K.; Lundström, K.; Jägerstad, M. Colour photographs for estimation of heterocyclic amine intake from fried pork chops of different RN genotypes indicate large variations. Food Qual. Prefer. 2005, 16, 91-101. [CrossRef]

19. Schechter, L. The apple and your eye: Visual and taste rank-ordered probit analysis with correlated errors. Food Qual. Prefer. 2010, 21, 112-120. [CrossRef]

20. Kildegaard, H.; Olsen, A.; Gabrielsen, G.; Møller, P.; Thybo, A.K. A method to measure the effect of food appearance factors on children's visual preferences. Food Qual. Prefer. 2011, 22, 763-771. [CrossRef]

21. Mielby, L.H.; Edelenbos, M.; Thybo, A.K. Comparison of rating, best-worst scaling, and adolescents' real choices of snacks. Food Qual. Prefer. 2012, 25, 140-147. [CrossRef]

22. Mielby, L.H.; Kildegaard, H.; Gabrielsen, G.; Edelenbos, M.; Thybo, A.K. Adolescent and adult visual preferences for pictures of fruit and vegetable mixes-Effect of complexity. Food Qual. Prefer. 2012, 26, 188-195. [CrossRef]

23. Arce-Lopera, C.; Masuda, T.; Kimura, A.; Wada, Y.; Okajima, K. Luminance distribution as a determinant for visual freshness perception: Evidence from image analysis of a cabbage leaf. Food Qual. Prefer. 2013, 27, 202-207. [CrossRef]

24. Manzocco, L.; Rumignani, A.; Lagazio, C. Emotional response to fruit salads with different visual quality. Food Qual. Prefer. 2013. [CrossRef] 
25. Sabinsky, M.S.; Toft, U.; Andersen, K.K.; Tetens, I. Validation of a digital photographic method for assessment of dietary quality of school lunch sandwiches brought from home. Food Nutr. Res. 2013. [CrossRef] [PubMed]

26. Woodward, H.E.; Cameron, C.D.; Treat, T.A. Enhancing the Conceptualization and Measurement of Implicit and Explicit Affective Evaluations: A Case Study in Disordered Eating. Soc. Pers. Psychol. Compass 2016. [CrossRef]

27. Lange, C.; Rousseau, F.; Issanchou, S. Expectation, liking and purchase behaviour under economical constraint. Food Qual. Prefer. 1998, 10, 31-39. [CrossRef]

28. Rodríguez Tarango, J.A. Introducción a la Ingeniería en Envase y Embalaje. In Manual de Ingeniería y Diseño en Envase y Embalaje Para la Industria de Los Alimentos, Farmacéutica, Química y de Cosméticos; Rodríguez Tarango, J.A., Ed.; Instituto Mexicano de Profesionales en Envase y Embalaje S.C: Ciudad de México, Mexico, 2003; pp. 1:1-1:6.

29. Jefferson, W.K.; Zunker, C.; Feucht, J.C.; Fitzpatrick, S.L.; Greene, L.F.; Shewchuk, R.M.; Baskin, M.L.; Walton, N.W.; Phillips, B.; Ard, J.D. Use of the Nominal Group Technique (NGT) to understand the perceptions of the healthiness of foods associated with African Americans. Eval. Program. Plann. 2010. [CrossRef]

30. Coker, J.; Tucker, J.; Estrada, C. Nominal group technique: A tool for course evaluation. Med. Educ. 2013, 47, 1145. [CrossRef] [PubMed]

31. Elliott, T.R.; Shewchuk, R.M. Using the nominal group technique to identify the problems experienced by persons living with severe physical disabilities. J. Clin. Psychol. Med. Settings 2002. [CrossRef]

32. MAPAMA Informe del Consumo de Alimentación en España 2018. Available online: https://www.mapa.gob.es/images/es/20 190807_informedeconsumo2018pdf_tcm30-512256.pdf (accessed on 17 December 2020).

33. Lyman, B. A Psychology of Food: More than a Matter of Taste; Springer Science \& Business Media: Berlin/Heidelberg, Germany, 2012.

34. Delbecq, A.L.; Van de Ven, A.H. A Group Process Model for Problem Identification and Program Planning. J. Appl. Behav. Sci. 1971, 7, 466-492. [CrossRef]

35. Jones, S.A.; Walter, J.; Soliah, L.A.; Phifer, J.T. Perceived motivators to home food preparation: Focus group findings. J. Acad. Nutr. Diet. 2014. [CrossRef]

36. BEDCA. Base de Datos Española de Composición de Alimentos [Spanish Database on Food Composition]; BEDCA: Madrid, Spain, 2013.

37. Pedret, R.; Sanier, L.; García, I.; Morell, A. Investigación de Mercados; Fundació per a la Universitat Oberta de Catalunya, Ed.; Editorial UOC: Barcelona, Spain, 2003.

38. Graveter, F.J.; Forzano, L.A.B. Research Methods for the Behavioural Sciences; Cengage Learning EMEA, Ed.; Gardners Books: Eastbourne, UK, 2008.

39. Carrillo, E.; Varela, P.; Fiszman, S. Packaging information as a modulator of consumers' perception of enriched and reduced-calorie biscuits in tasting and non-tasting tests. Food Qual. Prefer. 2012, 25, 105-115. [CrossRef]

40. Annunziata, A.; Vecchio, R. Consumer perception of functional foods: A conjoint analysis with probiotics. Food Qual. Prefer. 2013. [CrossRef]

41. Green, P.E.; Krieger, A.M.; Wind, Y. Thirty years of conjoint analysis: Reflections and prospects. Interfaces 2001, 31, 56-78. [CrossRef]

42. Addinsoft. Addinsoft XLSTAT Statistical and Data Analysis Solution; Addinsoft: New York, USA, 2020.

43. Rebollar, R.; Lidón, I.; Gil, I.; Martín, J.; Fernández, M.J.; Riveres, C.E. The influence the serving suggestion displayed on soft cheese packaging has on consumer expectations and willingness to buy. Food Qual. Prefer. 2016, 52, 188-194. [CrossRef]

44. Dernini, S.; Berry, E.M.; Serra-Majem, L.; La Vecchia, C.; Capone, R.; Medina, F.X.; Aranceta-Bartrina, J.; Belahsen, R.; Burlingame, B.; Calabrese, G.; et al. Med Diet 4.0: The Mediterranean diet with four sustainable benefits. Public Health Nutr. 2017, 20, 1322-1330. [CrossRef] [PubMed]

45. Henríquez Sánchez, P.; Ruano, C.; De Irala, J.; Ruiz-Canela, M.; Martínez-González, M.A.; Sánchez-Villegas, A. Adherence to the Mediterranean diet and quality of life in the SUN Project. Eur. J. Clin. Nutr. 2012, 66, 360-368. [CrossRef] [PubMed]

46. Maillot, M.; Issa, C.; Vieux, F.; Lairon, D.; Darmon, N. The shortest way to reach nutritional goals is to adopt Mediterranean food choices: Evidence from computer-generated personalized diets. Am. J. Clin. Nutr. 2011, 94, 1655. [CrossRef] [PubMed]

47. Fiszman, S.; Varela, P.; Díaz, P.; Linares, M.B.; Garrido, M.D. What is satiating? Consumer perceptions of satiating foods and expected satiety of protein-based meals. Food Res. Int. 2014. [CrossRef]

48. Barrett, E.M.; Foster, S.I.; Beck, E.J. Whole grain and high-fibre grain foods: How do knowledge, perceptions and attitudes affect food choice? Appetite 2020, 149. [CrossRef] [PubMed]

49. Gellynck, X.; Kühne, B.; Van Bockstaele, F.; Van de Walle, D.; Dewettinck, K. Consumer perception of bread quality. Appetite 2009, 53, 16-23. [CrossRef]

50. Sandvik, P.; Nydahl, M.; Kihlberg, I.; Marklinder, I. Consumers' health-related perceptions of bread-Implications for labeling and health communication. Appetite 2018, 121, 285-293. [CrossRef]

51. Teuber, R.; Dolgopolova, I.; Nordström, J. Some like it organic, Some like it purple and some like it ancient: Consumer preferences and WTP for value-added attributes in whole grain bread. Food Qual. Prefer. 2016, 52, 244-254. [CrossRef]

52. Martínez-Monzó, J.; García-Segovia, P.; Albors-Garrigos, J. Trends and innovations in bread, bakery, and pastry. J. Culin. Sci. Technol. 2013, 11. [CrossRef]

53. Mooney, K.M.; Lorenz, E. The Effects of Food and Gender on Interpersonal Perceptions. Sex Roles 1997, 36, 639-653. [CrossRef]

54. Mooney, K.M.; DeTore, J.; Malloy, K.A. Perceptions of women related to food choice. Sex Roles 1994, 31, 433-442. [CrossRef] 
55. Rappoport, L.; Peters, G.R.; Downey, R.; McCann, T.; Huff-Corzine, L. Gender and age differences in food cognition. Appetite 1993, 20, 33-52. [CrossRef]

56. Stanton, A.L.; Tips, T.A. Accuracy of calorie estimation by females as a function of eating habits and body mass. Int. J. Eat. Disord. 1990, 9, 387-393. [CrossRef]

57. Kimura, A.; Wada, Y.; Goto, S.I.; Tsuzuki, D.; Cai, D.; Oka, T.; Dan, I. Implicit gender-based food stereotypes. Semantic priming experiments on young Japanese. Appetite 2009. [CrossRef]

58. Kimura, A.; Wada, Y.; Asakawa, A.; Masuda, T.; Goto, S.I.; Dan, I.; Oka, T. Dish influences implicit gender-based food stereotypes among young Japanese adults. Appetite 2012. [CrossRef]

59. Rozin, P.; Hormes, J.M.; Faith, M.S.; Wansink, B. Is meat male? A quantitative multimethod framework to establish metaphoric relationships. J. Consum. Res. 2012, 39, 629-643. [CrossRef]

60. Vartanian, L.R.; Herman, C.P.; Polivy, J. Consumption stereotypes and impression management: How you are what you eat. Appetite 2007, 48, 265-277. [CrossRef] 